\title{
EFFECT OF LEARNING CULTURE, EMPOWERMENT, AND CYBER SKILL COMPETENCY ON SELF-ENGAGEMENT EMPLOYEES
}

\author{
S.R.M. Indah Permata Sari, \\ Defence Ministryof Indonesia Republic \\ indahunj@gmail.com
}

\begin{abstract}
The purpose of this research is to comprehensively about the effect of learning culture, empowerment, and cyber skill competence on self engagement of the employee in Directorate General of Potential for Defense Ministry of Defence Republic of Indonesia. The research methodology was survey with path analysis applied in testing hypothesis. It was conducted to 150 employees from population 241 employee who was selected in simple random way.Analysis and interpretation of data indicate that (1) learning culture has a positive direct effect in self engagement, (2) empowerment has a positive direct effect in self engagement, (3) cyber skill competence has a positive direct effect in self engagement, (4) learning culture has a positive direct effect in cyber skill competence, (5) empowerment has a positive direct effect in cyber skill competence, and (6) learning culture has a positive direct effect in empowerment
\end{abstract}

Keywords: Learning Culture, Empowerment, Cyber Skill Competency, Self Engagement.

Efforts needed to develop human resources in an organization or company is with the development of employment (employee development). It is basically an activity in preparing employees to be able to adapt to changes that occur so that it is expected to contribute productively in the achievement of corporate goals without ignoring its own interests. In other words, personnel development focuses on improving employee performance and career.

With the changing demands that occur, then it is very influential on human resources in preparing and maintaining expensive investments so that, can provide maximum earnings with optimal productivity. HR becomes one of the components that have an important role in the organization that starts from formulating goals, formulate strategies, up to the implementation stage of the strategy.

As an effort to employee development, the organization must be able to maintain a sense of "engagement" of each employee. Engagement of this employee is one of the main strengths to achieve organizational goals. Engagement is considered as the key to elevating organizations to a higher level and achieving goals. One of them "Self-Engagement" in which engagement is a major and important component in a person. Because every employee is expected to be willing to develop, by developing the competence they have, develop the learning culture especially to something new, and try to actively engage in employee empowerment.

Self-engagement in every task is an advantage for the organization, in this case the Ministry of Defense especially the Directorate General of Defense Potential of RI. One of the tasks in the directorate is related to cyber. Based on the results of observations made, has found as many as 55\% of employees who do not have a sense of "self-engagement". This is evidenced from the informal interview, that there are still employees who look lazy in the implementation of the task so impressed not to complete the task or also delaying the tasks associated with cyber. Employees feel that cyberrelated matters are not part of their duties so they are not yet concerned about learning about cyber. From the observations that tend to be low "self-engagement", it will automatically interfere with the performance of the organization. The condition of employee engagement level is quite low, of course, enough attention from the organization and can give birth to moral problems in the employee 
and can lead to the organization becomes ineffective because of employee performance is not maximal.

Based on previous information, it shows that low employee self-engagement in Directorate General of Pothan Ministry of Defense of RI, besides caused by the number of available employees not yet have qualification or ability in cyber field, but also influenced by several factors such as leadership, competence, organizational climate developing, working motivation, empowerment, trust, justice, learning culture, and the structure and mechanisms that exist within the organization. If observed from several factors, the factors of learning culture, empowerment and competence have an influence on the high low self-engagement employees and can determine both the poor performance of the organization. Employees who already have "self-engagement" but not yet have competence in the field of cyber, of course must be willing to develop a learning culture as an effort to develop competencies that have not been owned.

Cyber skill is one of the special skills that must be possessed by human resources in the field of cyber, one of which covers the mastery of information security (cyber security). That is, to keep no break-ins against the information system. Ministry of Defense RI should be able to manage human resources appropriately with attention to self-engagement of employees, conducive learning culture atmosphere, competence, and ability of employees in the hope of becoming a quality human resources and perform well as well.

Skilled human resources are needed in terms of the mastery of the cyber security system, so that there is a need for self-engagement from employees of any work related to cyber, the desire of employees to develop competence.

One of the approaches in increasing the cohesiveness of employees in the field of cyber is to prepare a condition of learning culture so that employees want to learn to develop information about cyber, then also the empowerment by the leadership by sending employees to attend seminars or workshops about cyber, as well as in the improvement competence cyber skill employees so that increased sense of attachment in the employees as a value and potential human resources within the organization. Therefore, the purpose of this approach as a picture and encourage the organization to concern to increase the competence of employees in an effort to improve self-engagement (selfengagement)

Culture is one factor that can affect employee engagement in an agency / company. The culture can change the behavior of every employee, from a positive or negative culture. Each agency / organization must have its own organizational culture that will certainly be a differentiator from other organizations, as well as with learning culture. Culture of learning in an institution / organization that is positive and conducive course will encourage every employee to have achievement motivation which can improve the performance of the organization.

Culture of learning in Directorate General of Pothan Kemhan RI can be said not yet conducive, this is evidenced by employees who still look cool or can be said also not too concerned and reluctant to find the completion of tasks that are difficult to do especially related to cyber, the atmosphere of learning environment that has not supported, then nor is there any increase in progress in work only stagnant, no sense of responsibility in the effort to improve the quality of work, and not yet have a good learning ethos.

Meanwhile, empowerment also needs to get serious attention because empowerment will add and reflect employees' confidence in their own ability. The process of empowerment within the organization can be done successfully if there is a sense of attachment of employees in the work.

Research conducted by Marius W. Stander and Sebastiaan Rothmann of North-West University, South Africa shows that "Employee engagement and psychological empowerment are important concepts to consider when dealing with changes in work and improving performance. Psychological empowerment increases employees' sense of personal control and motivates them to engage in work, which in turn results in positive managerial and organizational outcomes. "[1]So it 
can be said that both are important concepts in the changes and improvements in performance. With the empowerment is expected to increase employee motivation in an effort to bind them in the work.

Employee empowerment in DG Pothan has not been fully functional. This is demonstrated by the fact that employees have not been given an opportunity to extend their involvement in employment, employees have not been given the opportunity to participate in policy-making related to cyber, still uneven in terms of delegation of employees, leaders have not seen employees as strategic partners, every task completed, and has not involved employees in setting policy especially related to cyber.

The existence of cyber-crime phenomenon, even the importance of cyber security demands DG Pothan Kemhan RI to pay more attention to the importance of increasing the competence of cyber skill on Human Resources Directorate General of Defense to increase the confidentiality of information that must be maintained. Competence is a basic factor that an employee must possess which is demonstrated by applying knowledge and skills, so that if the employee has more or above average skills then it makes the employee different from employees who only have average or normal ability. Based on preliminary observations, the competence of employees of Directorate General of Pothan Kemhan RI has not been fully qualified in the field of cyber. This is evidenced by the lack of employees who have sufficient knowledge about cyber, there are employees who do not have a "motive" to develop competence, employees are still not able to adapt to increasingly sophisticated technology, employees tend to be in "comfort zone" and monotonous in every work.

Increased employee self-engagement can be done in a planned, directed and sustainable by improving the ability and professionalism of employees. In addition, supportive learning culture, employee empowerment and increased employee competence are high will lead to the birth of a strong commitment in the completion of the task so as to have a sense of self-engagement.

In line with the above description, this research is limited to the influence of learning culture, empowerment, and cyber skill competence, to the employee self-engagement in Directorate General of Defense Potential of Ministry of Defense of RI. Researchers need to increase the self-engagement of employees as an effort to employee development, so that the organization must be able to maintain a sense of "engagement" of each employee. Employee engagement is one of the main strengths to achieve organizational goals and the key to elevating organizations to a higher level and achieving goals.

Next will be discussed about the theoretical review of the four variables above. Starting from the term "employee engagement" introduced by Gallup, engagement is defined as an employee's "attachment" (in a positive sense) status to the workplace or the employer. Colquitt, et al, says "Employees who are" engaged "completely invest themselves and their energies into their job. "[2] when viewed from the outside, employees who have attachments will devote a lot of energy to their work, struggle, and take the initiative to complete the job. However, if viewed from within, then bound employees are more inclined to focus concentration and attention on their work, so it sometimes becomes unreasonable. The employees involved are interested in the task but sometimes they forget the time.

Furthermore, Macleod and Clarke, says about employee engagement as follows:

Employee engagement is the difference that makes the difference- and could make all the difference as we face the realities of globalised competition and of the millions of graduates and even more skilled and committed workers that China, India and other economies are producing each year.

The above statement, can mean that attachment is required by the employee, because it is the difference of every human being. Employees are the ones who make the difference and can unite all the differences while facing the reality of global competition and millions of graduates and even more skilled and committed workers produced by China, India and other economies each year. 
Furthermore, Robbins and Coulter define "employee engagement is closely related to their work, if they do not have a sense of being tied to work then they will be very unconcerned and lacked the energy spirit to complete the work. Thus it can be synthesized that self-engagement is a positive feeling that employees have with full meaning and enthusiasm towards a given task in the workplace, with indicators that are: persistent in the face of adversity, earnestness in work, pride of work, interest in work, and enthusiasm for work.

Every organization has a culture that is different from each other, the variety and kind varies. The organizational culture differences are related to the organizational dimension characteristics. One of them is learning culture, learning culture must assume that in the proper way must be given so that employees can be good to work environment, in this case is employees can act actively as problem solvers and learners.

Learning culture encourages employees to ask questions, share successes and lessons, and to disseminate and generate ideas. Noe, et.al says that "culture culture can be reflected in the performance management system and employee salary structure and awards for sharing knowledge. Learning culture creates conditions in which, the leadership encourages flexibility and experimentation for its employees.

Culture of learning is a culture oriented to the promotion and facilitated learning of the employees. Leaders should be able to create an atmosphere of learning culture as part of the organizational culture in the agency. This is in accordance with that defined by Schmitz, et.al that:

A learning culture as a culture oriented towards the promotion and facilitation of learning by its employees. It encourages the sharing and spreading of what is learned, aiming at the development and success of the organization ${ }^{[6]}$

Thus, with a learning culture it can encourage employees to share and disseminate something learned, aiming at the development and success of an organization

Armstrong says "learning culture is one that promotes learning because it is recognized by top management, line managers and employees generally as an essential organizational process to which they are committed and in which they engage continuously." [7] This means that the learning culture as a component to promote learning as it is recognized by top management, line managers and employees, as an important organizational process in which they are committed and engaged continuously.

Based on some concepts that have been described, it can be synthesized learning culture is a learning-oriented culture and encourage employees to improve knowledge, competence, and performance, with indicators that are: have perception, form motivation, ownership of the organization, skills in analyzing culture, and cooperation.

Empowerment is the involvement of employees who really mean. Empowerment can simply be interpreted as an activity done to make something more capable and have power or strength. Griffin, says that empowerment is "the process of enabling workers to set their own work goals, make decisions, and solve problems within their sphere of responsibility and authority." [8] Thus, empowerment is a process by which employees set themselves what the purpose of their performance, making decisions, and solving problems within their scope of responsibility and authority.

According to Luthans interpret Empowerment, namely "recognizing and releasing into the organization of the power that people have in their wealth of useful knowledge and internal motivation." [9] This means that empowerment is the power of someone who has a wealth of knowledge so that it can useful and internal motivating and recognizing and releasing into the organization.

Williams says "Empowerment is a feeling of intrinsic motivation," in which workers perceive their work to have meaning and perceive themselves to be competent. [10] Thus, if the 
leader wants employees to have strong expectations, then the leadership must empower employees to make decisions. By doing this it can motivate employees to take an active role rather than passively in each job.

Based on some conceptual that has been described, it can be synthesized that empowerment is the process of giving authority to employees throughout the organization to make important decisions and be responsible for the decisions taken, with the following indicators: clear authority, responsibility, trust, delegation, and support for employees.

Competence is the ability of a person in applying the knowledge and skills possessed of each employee, as one support to be able to perform tasks and responsibilities effectively, so as to achieve professional quality performance standards.

Furthermore, Malthis and Jackson say that "competencies are individual capabilities that can be linked to enhanced performance by individuals or teams." [11] In Malthis's opinion, competence is an individual's ability that can be attributed to performance that can be enhanced by the individual or team. In addition, according to Jackson et al, the definition of competence, "the competency to refer to the knowledge, skills, personality characterstics, and attitudes that make it possible for employees to perform work tasks and roles." [12] In that opinion, knowledge, skills, characteristics, personality, and attitudes that enable employees to perform tasks and job roles.

Based on the theory of taxonomy Blom according to Arikunto there are three domains or major domains in education are: first cognitive is an activity related to thinking through the process of recognition, understanding, application, analysis, synthesis and evaluation; second, psychomotor domains or skills that are closely related to work that fundamentally need to distinguish between skill and abilities; the three affective domains that are closely related to attitudes or values. [13]

Thus, the ability of cyber skill to be synthesized is the ability to perform or perform a job or task in the field of cyber based on skills and knowledge and supported by work attitude demanded by the work, with the following indicators (1) knowledge, (2) understanding , (3) application, (4) analysis, and (5) synthesis.Based on several theoretical studies and as above, the research hypothesis is proposed as follows: (1) There is a direct positive influence of learning culture towards self engagement. (2) There is a positive direct influence of empowerment to self engagement. (3) There is positive direct influence of cyber skill competence to self engagement. (4) There is a positive direct influence of learning culture on cyber skill competence. (5) There is a positive direct influence Empowerment of Cyber skill competence, and (6) There is a direct positive influence Culture learning to Empowerment.

\section{METHOD}

In this study, it was conducted at Directorate General of Defense Potential of Ministry of Defense RI where data collection was used questionnaire (questionnaire) instrument made for selfengagement $(\mathrm{Y})$ variable, learning culture (X1), and empowerment (X2) while for competence variable (X3 ) using a test instrument. Instrument development for each variable is presented starting from conceptual definition, operational definition, instrument grid, instrument validity test, and reliability calculation. Survey results and tests will be processed using path analysis method using Microsoft Excel 2010 and SPSS v.22 software, which will then generate the level of influence of the independent variable to the dependent variable to verify the hypothesis.

\section{RESULT}

Table 1. Summary of Hypothesis Testing Results Equation Model Structure 1 
Coefficients $^{\mathrm{a}}$

\begin{tabular}{|c|c|c|c|c|c|c|}
\hline \multirow{2}{*}{ Model } & \multicolumn{2}{|c|}{$\begin{array}{c}\text { Unstandardized } \\
\text { Coefficients }\end{array}$} & $\begin{array}{c}\text { Standardized } \\
\text { Coefficients }\end{array}$ & \multirow{2}{*}{ t } & \multirow{2}{*}{ Sig. } \\
\cline { 3 - 5 } & B & Std. Error & Beta & & \\
\hline \multirow{4}{*}{1} & (Constant) & 40,763 & 11,078 & & 3,680 &, 000 \\
\cline { 2 - 6 } & Culture of Learning (X1) &, 236 &, 066 &, 264 & 3,614 &, 000 \\
\cline { 2 - 6 } & Empowerment (X2) &, 314 &, 089 &, 259 & 3,541 &, 001 \\
\cline { 2 - 5 } & Cyber Skill Competency (X3) &, 397 &, 123 &, 241 & 3,235 &, 002 \\
\hline
\end{tabular}

Dependent Variable: Self Engagement $(\mathrm{Y})$

Table 2.Summary of Hypothesis Testing Results Equation Model Structure 2 Coefficients $^{\mathbf{a}}$

\begin{tabular}{|l|c|c|c|c|c|c|}
\hline \multirow{2}{*}{ Model } & \multicolumn{2}{|c|}{$\begin{array}{c}\text { Unstandardized } \\
\text { Coefficients }\end{array}$} & $\begin{array}{c}\text { Standardized } \\
\text { Coefficients }\end{array}$ & \multirow{2}{*}{ t } & \multirow{2}{*}{ Sig. } \\
\cline { 3 - 5 } & B & Std. Error & Beta & & \\
\hline \multirow{2}{*}{2} & (Constant) & $-14,324$ & 7,348 & & $-1,949$ &, 053 \\
\cline { 2 - 6 } & Culture of Learning (X1) &, 130 &, 043 &, 238 & 3,016 &, 003 \\
\cline { 2 - 5 } & Empowerment (X2) &, 173 &, 058 &, 234 & 2,969 &, 003 \\
\hline
\end{tabular}

Dependent Variable: Competence Cyber Skill (X3)

Table 3.Summary of Hypothesis Testing Results Equation Modeling Model 3

\section{Coefficients $^{\mathbf{a}}$}

\begin{tabular}{|c|c|c|c|c|c|}
\hline \multirow[t]{2}{*}{ Model } & \multicolumn{2}{|c|}{$\begin{array}{l}\text { Unstandardized } \\
\text { Coefficients }\end{array}$} & \multirow{2}{*}{$\begin{array}{c}\text { Standardized } \\
\text { Coefficients }\end{array}$} & \multirow[t]{2}{*}{$\mathbf{t}$} & \multirow[t]{2}{*}{ Sig. } \\
\hline & B & Std. Error & & & \\
\hline (Constant) & 96,366 & 6,711 & & 14,359 &, 000 \\
\hline Culture of Learning (X1) & ,167 & ,059 & ,227 & 2,841 & ,005 \\
\hline
\end{tabular}

Dependent Variable:Empowerment (X2)

Based on the calculation and testing of the path coefficient obtained calculation and test results, namely the influence between the variables as follows: (1) Culture Learning (X1) positive direct influence on Self-Engagement (Y) obtained by coefficient path py1 of 0.264 with a tcount of 3.61 , while ttable is $2.61(\alpha=0,01)$, because tcount $>$ ttable $(\mathrm{dk}=146, \alpha=0,01)$, then H0 is rejected. The results of this hypothesis testing show that there is a direct positive influence of learning culture (X1) on Self-Engagement (Y). (2) Empowerment (X2) has positive direct effect to Self-Engagement (Y) obtained by coefficient of py2 path equal to 0,259 with tcount equal to 3,54, while ttable equal to 2,61 at $\alpha=0,01$, because thitung $>\operatorname{ttabel}(\mathrm{dk}=146, \alpha=0.05)$, then $\mathrm{H} 0$ is rejected. The results of this hypothesis testing show that there is a direct positive influence of empowerment (X2) on SelfEngagement (Y). (3) The competence of cyber skill (X3) has positive direct effect on SelfEngagement $(\mathrm{Y})$ obtained by coefficient of py3 path equal to 0,241 with tcount 3,24 , while ttable is $2,61(\alpha=0,01)$ ttable $(\mathrm{dk}=146, \alpha=0,01)$, then $\mathrm{H} 0$ is rejected. The result of this hypothesis test shows that there is a positive direct effect of cyber skill (X3) to Self-Engagement (Y). (4) learning culture (X1) has a direct positive effect on cyber skill (X3). The coefficient of p31 line is 0,238 with tct value of 3.02, while ttable is $2,61(\alpha=0,01)$, because tcount $>$ ttable $(\mathrm{dk}=147, \alpha=0,01)$, then $\mathrm{H} 0$ 
is rejected which means that learning culture (X1) has a direct positive effect on cyber skill (X3). (5) empowerment (X2) has a direct positive effect on cyber skill (X3) competence obtained by p32 line coefficient 0,234 with tcount 2,97, while ttable is 2,61 $(\alpha=0,01)$, because thitung $>$ ttable $\mathrm{dk}=147, \alpha$ $=0.01$ ), then $\mathrm{H} 0$ is rejected, which means that empowerment $(\mathrm{X} 2)$ has a direct positive effect on the competence of cyber skill (X3). (6) learning culture (X1) have positive direct effect to Empowerment (X2) obtained by coefficient of p21 line equal to 0,227 with tcount 2,84, while ttable 2,61 $(\alpha=0,01)$, because titung $>$ ttabel $(\mathrm{dk}=148, \alpha=0.01)$, then $\mathrm{H} 0$ is rejected, which means that learning culture (X1) has a direct positive effect on Empowerment (X2).

\section{DISCUSSION}

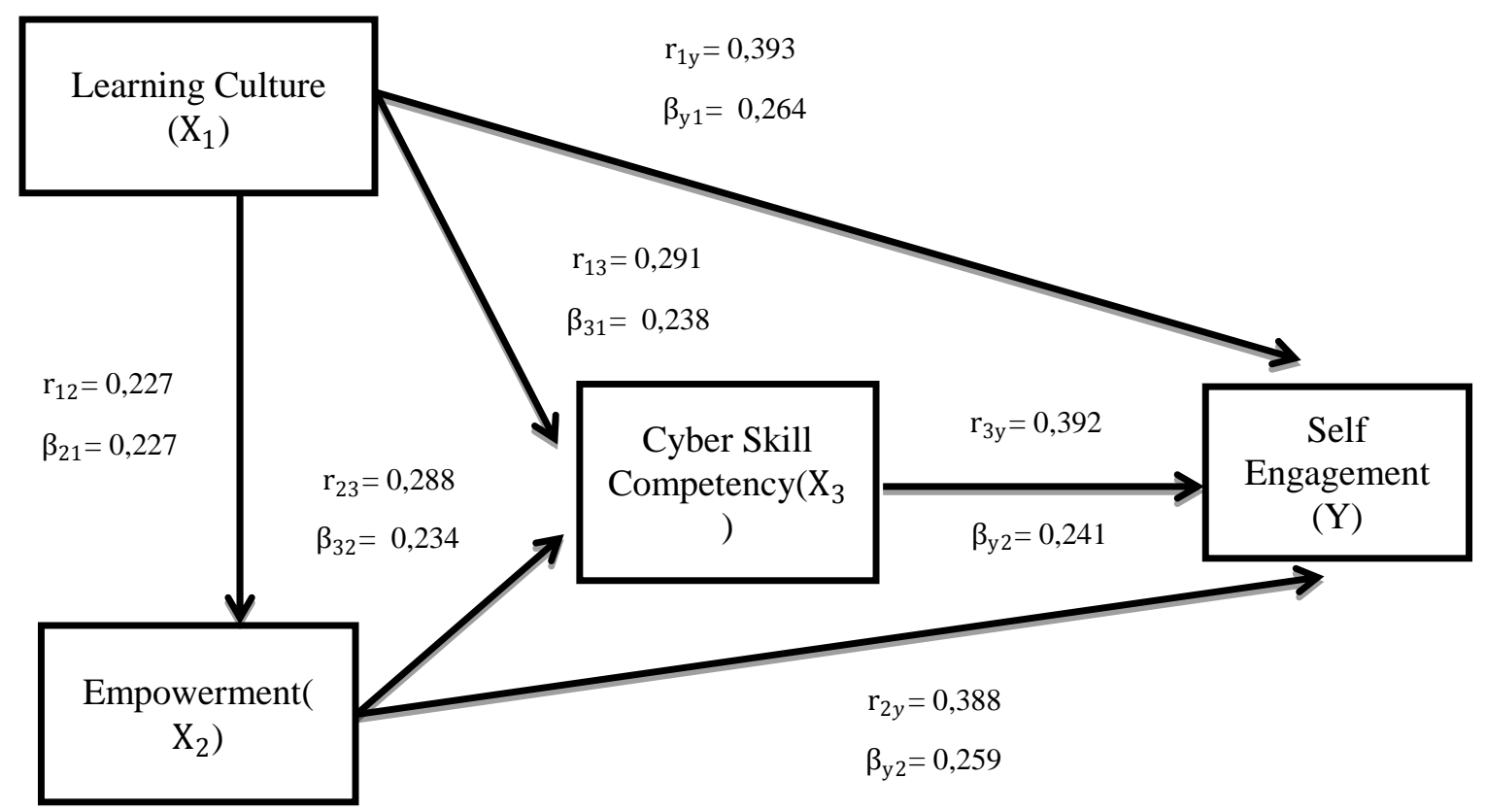

\section{Figure 1.Models of Structural Relationships between VariablesBased on the Analysis of Path Result}

Discussion of research results as follows: (1) Culture of learning directly affects positive self-engagement. As Albrecht says that the most obvious behavior of engagement is the effort of that person. [14] The person engaged involves working hard, working, and being fully engaged in the job. They focus on what they do by exerting their energies. Then also McBain's research suggests that organizational culture as one of the drivers of employee engagement. [15] Thus, the better and conducive cultural learning in the agency then it can improve self-engagement of employees of Directorate General of Pothan Kemhan RI. (2) Self Engagement is directly affected positively by empowerment. Noe, et al says that "Employee empowerment means giving employees the responsibility and authority to make decisions about all aspects of product development or customer service". Empowerment is considered able to grow and increase the creativity of employees, while creativity itself is the foundation for the growth of innovation. Thus, employees are given the opportunity to create innovation, so employees feel attached to the organization. Therefore, empowerment is seen as an important part in order to ensure the survival of the organization in a competitive environment. Thus, the more empowered employees can increase self-engagement employees DG Pothan Kemhan RI. (3) The competence of cyber skill has a direct positive effect on Self Engagement. May et al. says "engagement, as self-employment and expression physically, cognitively, and emotionally during role performances. Attachment to work as a positive psychological construct, to measure attachment there are three separate factors such as cognitive, 
emotional, and physical factors. In attachment, it is usually associated with increased competence on performance outcomes, and contributes to the assignment of individuals to their work. Thus, the increased competence of cyber skill hence can increase self engagement officer of Directorate General of Pothan Kemhan RI. (4) Culture of learning directly affects positively to the competence of cyber skill. Thus, increasing the work culture in the agency then it can increase the competence of cyber skill of DG Pothan Kemhan RI employees. (5) Empowerment directly affects positively to the competence of cyber skill. Luthans who say that Empowerment, which is "recognizing and releasing into the organization of the power that people have in their wealth of useful knowledge and internal motivation." [17] This means that empowerment is the power of someone who has a wealth of knowledge so that can be useful and motivate internally and recognize and release into the organization. Thus, the increasing employee empowerment can increase the competence of cyber skill employee of Directorate General of Pothan Kemhan RI. (6) Learning culture has a direct positive effect on empowerment. The learning culture created by the organization, able to develop the existing competencies so that employees feel like empowered by the organization. Thus, the increasing atmosphere of learning culture in the agency then it can increase the self-engagement of employees of Directorate General of Pothan Kemhan RI.

\section{CONCLUSION}

Based on the above findings, it can be concluded that (1) Culture of learning has a direct positive effect on Self Engagement. This means that improving the implementation of learning culture within the organization will lead to increased self-engagement on DG Staff of Defense Potential. (2) Empowerment has a direct positive effect on Self Engagement. This means that increased empowerment will lead to increased self-engagement on DD officers of Defense Potential. (3) Cyber Skill Competence has a direct positive effect on Self Engagement. It means that the increasing competence of cyber skill of employees will lead to increased self-engagement on DG Staff of Defense Potential. (4) Culture of learning have a direct positive effect on Cyber Skill Competence. This means that improving the implementation of learning culture in the organization will result in increased competence of cyber skill on DG Staff of Defense Potential. (5) Empowerment has a direct positive effect on Cyber Skill Competence. This means that increased employee empowerment will result in increased competence of cyber skill on DG Staff of Defense Potential. (6) Culture of learning has a direct positive effect on Empowerment. This means that improving the implementation of learning culture within the organization will result in increased empowerment of DG officers of Defense Potential

\section{REFERENCES}

Albrecht, S. L. (2010). Research and Practice. Handbook of Employee Engagement Perspective, Issues. UK: MGP Books Group.

Armstrong, Michael. (2010).Armstrong's Essential Human Resource Management Practice: A Guide To People Management. Philadelphia: Kogan Page.

Arikunto, Suharsimi.(2015). Dasar-dasar Evaluasi Pendidikan. Jakarta: Bumi Aksara.

Colquitt, Jason A., Jeffery A. Lepine, and Michael J. Wesson. (2013).Organizational Behavior. New York: McGraw-Hill.

Griffin,Ricky W. (2013). Management. South Western: Cengage Learnng.

Jackson, Susan E., Michael A. Hitt, and Angelo S. DeNisi (eds). (2003). Managing Knowledge for Sustained Competitive Advantage : Designing Strategies for Effective Human Resource Management. San Fransisco: Jossey-Bass.

Luthans, Fred. (2011).Organizational Behavior: An Evidence-Based Approach. New York: McGrawHill/Irwin. 
McBain. (2007). The Practice of Engagement: Research into Current Employee Engagement Practice. Strategic HR Review. Vol. 6. Iss: 6.

MacLeod, D. dan N. Clarke. (2009). Engaging for Success: Enhancing Performance through Employee Engagement. UK: Crown Copyright.

Malthis, Robert L. dan John H. Jackson. (2008). Human Resource Management, $12^{\text {th }}$ Edition. Mason: Thomson South-Western.

Nelson, Debra dan Cary L Cooper. (2007).Positive Organizational Behavior. London: SAGE Publications.

Noe,Raymond A., John R. Hollenbeck, Barry Gerhart, Patrick M. Wright. (2014). Fundamentals of Human Resource Management, Sixth Edition. New York: McGraw-Hill/Irwin.

Robbins, Stephen P., dan Mary Coulter. (2016).Management, $13^{\text {th }}$ Edition. London: Pearson Education.

Schmitz,Susana; Teresa Rebelo, Francisco J. Gracia, and Ines Tomas. (2014). Learning Culture And Knowledge Management Processes: To What Extent Are They Effectively Related? Journal of Work and Organizational Psychology.

Stander, Marius W. dan Sebastiaan Rothmann. (2010). Psychological empowerment, job insecurity, and employee engagement. SA. Journal of Industrial Psychology, 36 (1).

Williams, Chuck. (2011).Management. South-Western: Cengage Learning. 